\title{
Las Bodas de Camacho a través de algunas representaciones figurativas
}

\author{
Aurora Miró Domínguez \\ Universidad Rey Juan Carlos de Madrid \\ Manuel Alvar Ezquerra \\ Universidad Complutense de Madrid
}

RESUMEN: A través de unas pocas imágenes sobre el episodio de las Bodas de Camacho, se hace un recorrido por los distintos estilos artísticos que se van sucediendo desde el siglo XVIII al XX, a partir de los modelos iconográficos de Francia, Inglaterra y España.

PALABRAS CLAVE: Arte de los siglos XVIII y XIX, Las Bodas de Camacho, Don Quijote.

\section{The Wedding of Camacho through some Figurative Representations}

ABSTRACT: This paper analyses the iconography of «The Wedding of Camacho», an episode of El Quijote, through some images of different styles of France, England and Spain, from eighteenth century to twentieth.

KEY WORDS: Eigthteenth and Ninetennth Century Art, Las Bodas de Camacho, Don Quijote.

Recibido: 25 de febrero de 2013 / Aceptado: 1 de abril de 2013.

"Aunque las Estampas que se ponen en los Libros, casi siempre se estiman como unos meros adornos, y por la mayor parte están compuestos de manera que parecen de poca mayor importancia que los otros pulimentos de la encuadernación, y únicamente sirven de divertimiento a los que se pagan de solar galanuras, sin embargo las Estampas pueden servir a otro fin más elevado, representando y dando luz a muchas cosas, las cuales por medio de las palabras no se pueden expresar tan perfectamente».

John Oldfield, "Advertencias a las estampas", en Vida y hechos del ingenioso hidalgo Don Quixote de la Mancha, Londres, J. y R. Tonson, 1738, p. II

«Don Quijote es la figura literaria española que ha tenido más proyección universal»". Si, como dice Pérez Sánchez, la novela en un primer momento fue tomada como una obra cómica, con el tiempo adquirió una carácter más profundo al ser considerada como un símbolo de la "lucha eterna entre la realidad y la razón de una parte, y la imaginación y el deseo ideal de otra»² y se convirtió

\footnotetext{
* MIRÓ DOMíngUEZ, Aurora y ALVAR EZQUERRA, Manuel: "Las Bodas de Camacho a través de algunas representaciones figurativas", Boletín de Arte, n. ${ }^{\circ}$ 34, Departamento de Historia del Arte, Universidad de Málaga, 2013, pp. 201-222, ISSN: 0211-8483.

1 PÉREZ SÁNCHEZ, Alfonso E., "El Quijote en la pintura», en ALVAR, Carlos et al., La imagen del Quijote en el mundo, Centro de Estudios Cervantinos, Lunwerg Editores, 2004, pp. 65-99, en especial la p. 65.

2 lbid., p. 65.
} 
en un referente universal que brindaba ocasión de meditaciones inacabables e interpretaciones múltiples.

El episodio de las Bodas de Camacho constituye los capítulos XIX, XX y XXI de la segunda parte del Quijote de Miguel de Cervantes ${ }^{3}$. Comienza al final del capítulo XIX («Donde se cuenta la aventura del pastor enamorado, con otros en verdad graciosos sucesos") cuando don Quijote y Sancho se encuentran con un grupo de aldeanos y unos estudiantes, a los cuales el hidalgo se presenta como caballero andante y les pregunta a qué se debe el bullicio que oyen a lo lejos. Los estudiantes les cuentan que son las bodas del rico Camacho con una bella aldeana Ilamada Quiteria, y les invitan a que asistan al festejo. Les mencionan igualmente a Basilio, el pobre pastor enamorado de Quiteria, que esta había abandonado por el rico labriego. Está anocheciendo y los aldeanos les ofrecen pasar la noche en el pueblo, pero don Quijote prefiere quedarse a la intemperie, pues, según él, "ser costumbre de los caballeros andantes dormir por los campos y florestas antes que en los poblados». El capítulo XX («Donde se cuentan las bodas de Camacho el rico, con el suceso de Basilio el pobre») comienza con la aurora y don Quijote tiene que despertar a Sancho "con el cuento de la lanza", pues de otra forma no había manera de espabilarlo. En seguida, le llega a Sancho, somnoliento, "un tufo y olor harto más de torreznos asados que de juncos y tomillos: bodas que por tales olores comienzan, para mi santiguada que deben de ser abundantes y generosas". Se acercan al pueblo y observan desde lejos todos los preparativos de las bodas: la abundancia de viandas y guisos, de postres y dulces deliciosos, de personajes que intervenían en su preparación, que hicieron que el glotón de Sancho se acercara a probar. Don Quijote, por su parte, se fijaba más en la riqueza de las vestimentas de todos los participantes y de los jaeces de sus monturas, en las muchas y diferentes danzas de zagales y doncellas que lo dejaron maravillado. Tras ellas se representó una danza de artificio, donde se entremezclan la música, la poesía, la alegoría, la danza, la arquitectura fingida, etc. El capítulo XXI («Donde se prosiguen las bodas de Camacho, con otros gustosos sucesos») narra el engaño y la burla a todos de Basilio que irrumpe en la ceremonia y finge quitarse la vida para conseguir la mano de Quiteria. Al final, después de un amago de pelea entre los bandos de Camacho y Basilio, intervino don Quijote y logró la paz entre todos. En resumen, es el triunfo del Amor sobre el Interés.

3 Para nuestras citas utilizamos la versión del Centro Virtual Cervantes <http://cvc.cervantes.es/ literatura/clasicos/quijote/> (consulta realizada el 19 de enero de 2013). 
El pasaje de las Bodas de Camacho no fue el más popular ni el preferido por los artistas y, en comparación con otros episodios, se representa raras veces. No obstante, a lo largo de los siglos XVIII y XIX gozará de un relativo éxito, y son más frecuentes las imágenes sobre el tema, además de haber surgido algunas representaciones teatrales ${ }^{4}$.

Como sabemos, el Quijote salió a la luz en Madrid en 1605, sin imágenes, como sucedía en la primeras ediciones. La segunda parte, que es la que nos interesa, apareció en 1615. La primera traducción del Quijote se hizo al inglés, en Londres, realizada por Thomas Shelton en 1612. El mismo Shelton completaría en 1620 su versión de la obra con la incorporación de la segunda parte. A partir de entonces se hacen traducciones a otros idiomas. La obra tuvo muy pronto un éxito enorme en Europa y comenzaron las traducciones a otras lenguas, las recreaciones y reinterpretaciones que muchas veces fueron abusivas, quejándose de ello el propio Cervantes 5 .

Muchas de las ediciones que fueron apareciendo a lo largo del siglo XVII, tanto en Londres, como en Amberes y en otros lugares, iban acompañadas de grabados de los protagonistas en los frontispicios. Luego, tímidamente, empezaron a representarse algunos de los episodios. Pero la característica común de todas esas imágenes es la de unos personajes, unas indumentarias, unos ambientes y paisajes totalmente ajenos a los castellanos y españoles. Es como si al traducir el Quijote a otras lenguas, quisieran hacer del caballero andante un personaje que fuera más cercano a ellos y a su vida para que la obra tuviera un mayor éxito ${ }^{6}$. Es habitual que las primeras ilustraciones de los distintos

4 Cfr. CARO, Ceferino, "Amor contra interés, hijos contra padres: Las Bodas de Camacho en el siglo XVIII", Anales Cervantinos, vol. XXXVIII, 2006, pp. 165-202.

5 "Me parece que el traducir de una lengua en otra, como no sea de las reinas de las lenguas, griega y latina, es como quien mira los tapices flamencos por el revés, que, aunque se veen las figuras, son llenas de hilos que las escurecen, y no se veen con la lisura y tez de la haz; y el traducir de lenguas fáciles, ni arguye ingenio ni elocución, como no le arguye el que traslada ni el que copia un papel de otro papel. Y no por esto quiero inferir que no sea loable este ejercicio del traducir; porque en otras cosas peores se podría ocupar el hombre, y que menos provecho le trajesen" (Quijote, II, 62). Tomado de ALVAR, Carlos, "El Quijote en el mundo. Traducciones de los siglos XVII y XVIII», en TORRES SANTO DOMINGO, Marta (coord.), Don Quijote en el Campus. Tesoros Complutenses, Catálogo de Exposición, Biblioteca Histórica "Marqués de Valdecilla», abril-julio de 2005, Madrid, Universidad Complutense de Madrid, 2005, pp. 153-171, en especial las pp. 173-174.

6 En palabras de José Manuel Lucía: «los gestos y vestimentas de los personajes del Quijote, los paisajes de sus aventuras y la representación de los objetos más cotidianos se van a transformar según la geografía y el tiempo en donde se publiquen: pura estrategia editorial, que tendrá también su importancia en la recepción del libro. En otras palabras: el Quijote se escribió en español reflejando una geografía y unas costumbres muy particulares: las de Castilla a principios del siglo XVII; pero el Quijote se ilustró en Inglaterra, en Francia y en Flandes, transformando completamente el universo iconográfico que imaginaron su autor y sus primeros lectores", El Quijote ilustrado: Siglos XVII-XVIII, Catálogo de 
episodios se copiasen hasta la saciedad en diversas ediciones posteriores, del mismo país o de otros países.

La primera edición en lengua española que contiene estampas es la impresión de 1662, hecha en Bruselas por el conocido editor de obras españolas Jean Mommaert. En esa salida, por vez primera se cambió el título de la edición príncipe por el de: Vida y Hechos del Ingenioso cavallero..., adoptado en ediciones posteriores. Es, además, una de las dos primeras ediciones con ilustraciones en el interior (dos frontispicios y 16 grabados, 8 por volumen) ${ }^{7}$, pues en las anteriores únicamente se grabaron los frontispicios y las portadas ${ }^{8}$.

No será hasta el siglo XVIII cuando se comiencen a representar de forma regular los pasajes del episodio que hemos elegido. Es esta centuria uno de los momentos álgidos de ediciones de la obra de Cervantes acompañadas de ilustraciones. Según José Manuel Lucía Mejías, en las primeras imágenes del Quijote de los siglos XVI y XVII prevalece el modelo iconográfico holandés y la consideración del libro de Cervantes como una obra de entretenimiento y popular, mientras que durante el siglo XVIII surgen tres nuevos modelos iconográficos. El primero de ellos es el modelo iconográfico francés, cuyo impulsor es el pintor francés Charles Antoine Coypel $^{9}$ (1694-1752). Es la entrada de don Quijote en las artes mayores. Coypel creó, a partir de 1715, a la edad de 20 años, los cartones para los tapices realizados en la Fábrica Real de los Gobelinos, serie considerada como su obra más importante. Llegó a ser director de la Academia de Arte de París y primer pintor del rey, lo cual hizo que esas imágenes pronto adquirieran gran fama y fuesen apreciadas, por lo que se difundieron por toda Europa ${ }^{10}$.

Coypel tuvo una especial predilección por la segunda parte del Quijote, pero no inventó todas las representaciones, sino que se inspiró en los grabados de una edición de 1706 realizados por Jacques Harrewyn ${ }^{11}$ (1660-1722). Además de los cartones, Coypel realizó una serie de dibujos de sus composiciones quijotescas, que hizo grabar, demostrando una clara visión empresarial, ya que

Exposición, Centro de Estudios Cervantinos, <http://www.centroestudioscervantinos.es/quienes.php?d pto $=7 \&$ idbtn $=1035 \&$ idpadre $=1013 \&$ itm $=7.1>$ (consulta realizada el 20 de enero de 2013).

7 Cfr. PEETERS-FONTAINES, Jean, Bibliographie des impresions espagnoles des Pays-Bas méridionaux, I, Nieuwkoop, B. de Graaf, 1965, p. 124, ficha 229.

8 OSTERC, Lúdovik, Los Quijotes de la colección Franz Mayer, México, Fideicomiso Cultural Franz Mayer, 1981 (n. ${ }^{\circ} 38$ ).

9 LUCÍA MEGÍAS, José Manuel, Leer el Quijote en imágenes. Hacia una teoría de los modelos iconográficos, Madrid, Biblioteca Litterae Calamabur, Calambur Editorial, 2006, pp. 248 y ss.

10 LUCÍA MEGÍAS, José Manuel, El Quijote ilustrado..., s. p., dice que "se tejieron más de 240 tapices desde 1718 a 1792 y la fábrica no dejó de fabricarlos".

11 HARTAU, Johannes, "Algunas representaciones iconográficas de Don Quijote en Francia», en Mélanges de la Casa de Velázquez, 37-2, 2007, p. 15. <http://mcv.revues.org/1692> (consulta realizada el 5 de febrero de 2013). 
así se aseguró los derechos de reproducción de los cartones entre los grabadores. Pronto sus dibujos llegaron a la imprenta y adornaron numerosísimas ediciones del Quijote que se extendieron hasta nuestros días.

Charles Antoine Coypel pertenecía a una familia de artistas renombrados, formado con su padre, Antoine Coypel (1661-1722), el más famoso de toda la familia. Nos dejó una visión del Quijote elegante y palaciega, muy acorde con el gusto imperante en los círculos versallescos del momento. Su estilo es el del rococó, un estilo aristocrático, sofisticado y teatral, no en vano él era también dramaturgo y siempre se sintió muy atraído por el teatro.

Hasta ese momento, las ilustraciones del Quijote tenían un carácter popular y burlesco, y a partir del siglo XVIII se vestirá de lujo, haciéndose cortesano, especialmente en Inglaterra y en Francia. Ello sucedió como consecuencia del trabajo de Coypel, punto culminante de esta corriente palaciega y galante.

Precisamente, en la Biblioteca Histórica del Marqués de Valdecilla de la Universidad Complutense de Madrid hay un tapiz, procedente de una colección particular, que fue tejido en la fábrica de los Gobelinos y representa uno de los episodios de las Bodas de Camacho: "Don Quijote defiende a Basilio»12. El tema es el del fingido suicidio de Basilio para conseguir su unión con Quiteria ${ }^{13}$. Los mismos donantes también han pasado a esta biblioteca algunos grabados que pertenecen al primer álbum con once estampas comercializado por el editor y grabador Louis Surugue (ca. 1686-1762), con los dibujos de Coypel. Según la

12 Con un tamaño de 221 × 332 centímetros. Cfr. MENÉNDEZ, Sofía, "Un tapiz inspirado en el Quijote entra a formar parte de la Biblioteca Histórica de la Complutense», en Revista Universitaria "La Huella Digital.com", publicado el 13 de enero de 2012 <http://www.lahuelladigital.com/un-tapiz-inspirado-enel-quijote-para-la-universidad-complutense-de-madrid/c>; véase también LIZÁRRAGA, Juan Manuel, «Nueva donación de Carmen y Justo Fernández a la Biblioteca Histórica: dos grabados franceses del siglo XVIII sobre el Quijote» <http://www.ucm.es/BUCM/blogs/Foliocomplutense/5003.php\#. UR4fBh0yKNA> y «Donación de Carmen y Justo Fernández de la primera edición del grabado de las bodas de Camacho inspirado en los cartones para tapices de Coypel» <http://www.ucm.es/BUCM/blogs/ Foliocomplutense/7028.php\#.UQVnUB28-NA»; además, LÓPEZ REY, María, "Memoria del proceso de Conservación-Restauración del tapiz Las Bodas de Camacho" <http://www.ucm.es/BUCM/foa/doc18853. pdf> (consultas realizadas el 30 de enero de 2013).

13 "Ante la fingida muerte de Basilio, Quiteria, "más dura que un mármol y más sesga que una estatua", recuerda al emblema 67 de Alciato, que, en relación con el vicio de la soberbia, recurre al mito de Níobe, y la dureza de sentimientos en las mujeres: "He aquí la dureza de una estatua, y un mármol sacado de otro mármol: la insolente Níobe, que se atrevió a compararse con los dioses. La soberbia es vicio femenino, y denota desfachatez y dureza de sentimientos, cual la de las rocas [...]. Basilio, por su parte, no parece menos aficionado a estos elementos. Su sayo es negro, jironado de carmesí a llamas: negro de luto y llamas del amor que lo consume, como se ha señalado: vestido emblemático, por tanto, lo mismo que la corona que se coloca, de funesto ciprés. Alciato, en el emblema 198 dedicado al ciprés, comenta este valor funeral, proveniente de la costumbre de cubrir las sepulturas de los hombres ilustres con cipreses". PINILLO, Carmen, "Emblemas en el Quijote. El episodio de las bodas de Camacho", Criticón, 71, 1997, pp. 93-104, en especial las pp. 102 y 103. 
mayoría de los autores puede datarse con bastante seguridad entre 1723 y 1724 o inicios de $1725^{14}$.

Entre los varios dibujos que Coypel dedicó a las Bodas de Camacho, el más interesante es el de Cupido canta una copla a una dama (danza hablada) o Entrée de l'Amour et de la Richesse aux Noces de Gamache [1], que corresponde al contenido del capítulo XX de la parte segunda del Quijote. En esta espléndida imagen se refleja la influencia del teatro de tipo cortesano, alegórico y simbólico tan en boga en el siglo XVIII. En ella se percibe esa perfecta armonía entre el gusto artístico y la vocación teatral de Coypel, que ya hemos mencionado más arriba, en especial su inclinación hacia el teatro alegórico y moral ${ }^{15}$. Las indumentarias y los personajes, así como las posturas y ademanes, pertenecen al estilo rococó.

Este es uno de los episodios más emblemáticos de las Bodas de Camacho: la danza hablada entre los cortejos de Cupido y del Interés. En el texto se la denomina "danza de artificio de las que llaman habladas»" ${ }^{16}$, y la interpretación de Coypel sigue con relativa fidelidad la descripción de Cervantes, apartándose,

14 «Hace poco más de un año en Nueva donación de Carmen y Justo Fernández a la Biblioteca Histórica: dos grabados franceses del siglo XVIII sobre el Quijote dábamos cuenta de la donación de dos aguafuertes que reproducen el mismo pasaje del Quijote sobre las bodas de Camacho en el que también está inspirado el tapiz que Carmen y Justo Fernández habían cedido en depósito a la Biblioteca Histórica unos meses antes. Hoy, gracias a la generosidad de nuestros mecenas, podemos añadir otro grabado más sobre este pasaje del texto cervantino a nuestra colección, que tiene además el valor de pertenecer a la primera edición que se grabó y vendió inspirada directamente en el cartón para tapiz que diseñó y realizó Charles Antoine Coypel (1694-17529. En la primera edición los grabados del álbum recogen al pie de la imagen la mención: "Se vend a Paris chéz L. Surugue Montagne Ste. Geneviève avec privilege du Roi", que los distingue claramente de otras ediciones posteriores". LIZÁRRAGA, Juan Manuel, "Donación de Carmen y Justo Fernández de la primera edición del grabado de las bodas de Camacho inspirado en los cartones para tapices de Coypel», Folio Complutense. Noticias de la Biblioteca Histórica de la UCM. <http://www.ucm.es/BUCM/blogs/Foliocomplutense/7028.php\#.UQVnUB28-NA> (consulta realizada el 13 de enero de 2013).

15 En realidad, Cervantes describe tanto esta danza como la anterior de las pastoras como representaciones teatrales. Véase al respecto, GONZÁLES MORENO, Fernando y URBINA, Eduardo, "Don Quichotte conduit par la Folie: la herencia de Charles-Antoine Coypel en las ediciones ilustradas del Quijote", Cervantes Project (Texas A\&M University/UCLM), en Anuario de Estudios Cervantinos, IV, Editorial Academia del Hispanismo, 2008, pp. 1-31, en especial la p. 13, en <http://cervantes.tamu.edu/ pubs/AEC_4_Moreno_y_Urbina.pdf> (consulta realizada el 13 de enero de 2013).

16 «[...] Tras esta entró otra danza de artificio y de las que llaman habladas. Era de ocho ninfas, repartidas en dos hileras: de la una hilera era guía el dios Cupido, y de la otra, el Interés; aquel, adornado de alas, arco, aljaba y saetas; este, vestido de ricas y diversas colores de oro y seda. Las ninfas que al Amor seguían traían a las espaldas en pargamino blanco y letras grandes escritos sus nombres. Poesía era el título de la primera; el de la segunda, Discreción; el de la tercera, Buen linaje; el de la cuarta, Valentía. Del modo mesmo venían señaladas las que al Interés seguían: decía Liberalidad el título de la primera; Dádiva el de la segunda; Tesoro el de la tercera, y el de la cuarta Posesión pacífica. Delante de todos venía un castillo de madera, a quien tiraban cuatro salvajes, todos vestidos de yedra y de cáñamo teñido de verde, tan al natural, que por poco espantaran a Sancho. En la frontera del castillo y en todas cuatro partes de sus cuadros traía escrito: Castillo del buen recato. Hacíanles el son cuatro diestros tañedores de tamboril y flauta. Comenzaba la danza Cupido, $y$, habiendo hecho dos mudanzas, alzaba los ojos y flechaba el arco contra una doncella que se ponía entre las almenas del castillo [...]", Quijote, II, XX. 


- artículos Las Bodas de Camacho...

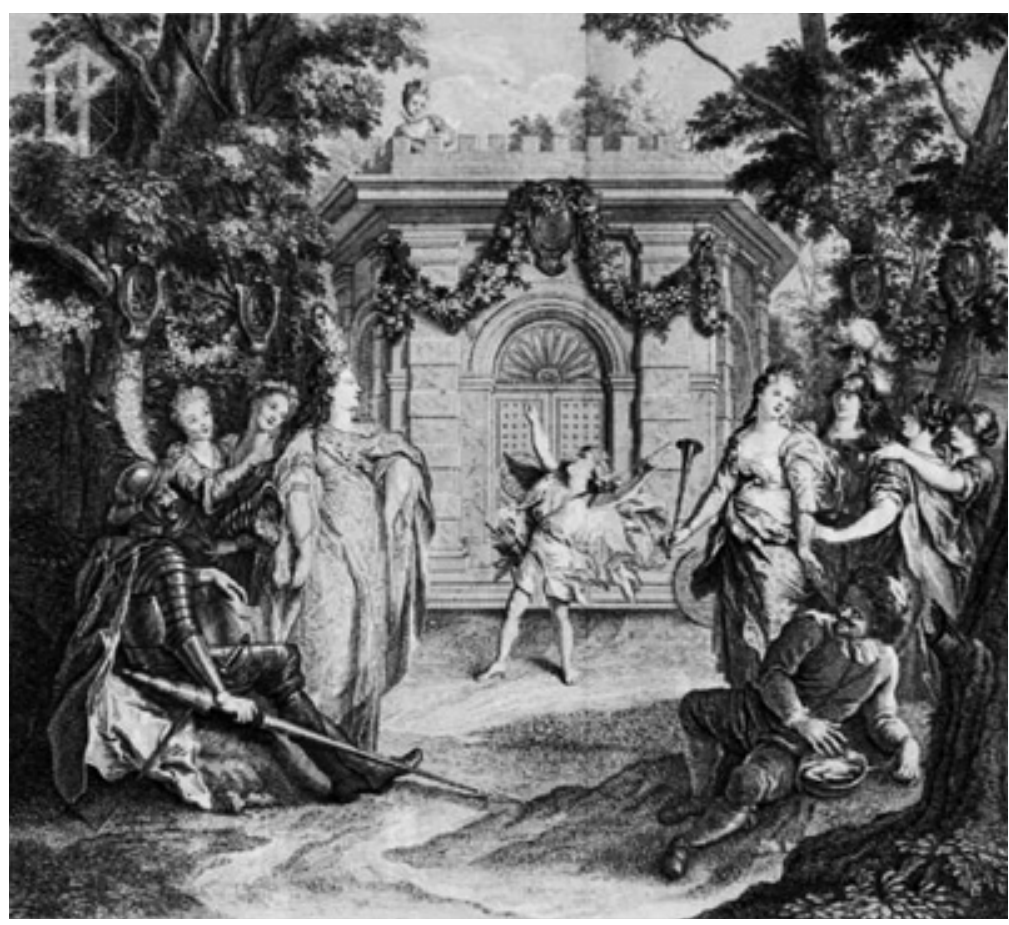

1. Charles-Antoine Coypel, Entrée de l'amour et de la Richesse aux Noces de Gamache, en Les aventures de Don Quichotte (estampas sueltas), edición de Louis Surugue, París,

1723. Grabador: Louise-Magdeleine Cochin Horthemels.<http://hera.uclm.es:8080/ Iconography/DQIIMAGES/images/545/s1723-Paris-Surugue-003.jpg>

eso sí, en las características ambientales y de los personajes, muy alejadas de las castellano manchegas, que suponemos en el original

La composición de la estampa resulta muy equilibrada. Se emplaza en un paisaje boscoso, en la cual se sigue el enfrentamiento alegórico del Amor (Cupido) y del Interés por la conquista de una doncella encerrada en un castillo (castillo del Buen Recato) de la narración cervantina. En el centro, Cupido (adornado con alas, arco, aljaba y saetas) baila delante del castillo donde se protege una doncella (aludiendo a Quiteria, que se debate entre el Interés o el Amor ${ }^{17}$ ) asomada en las almenas. A la derecha aparecen cuatro figuras femeninas alegóricas de gran belleza que forman parte del séquito de Cupido: la Poesía (con

17 En esto recuerda bastante al tema de Hércules en la encrucijada, muy característico de esa época. 
la trompeta de la Fama), la Nobleza o Buen Linaje (IIlustre Naissance), la Valentía (Valeur) y la Sabiduría (Sagesse, en sustitución de la Discreción), que se muestra como Atenea con el casco. La Sabiduría no aparece en el texto de Cervantes, pero sí en la traducción realizada al francés por François Filleau de Saint-Martin (1632-ca. 1695) en 1677-78 (en la que se inspira Coypel), que introduce ligeras variantes de su cosecha en este episodio. Esta parte de la composición representa alegóricamente los valores de Basilio.

A la izquierda de la imagen aparece el séquito del Interés (más bien Riqueza), que alude a los intereses de Camacho. Está formado por las figuras de la Liberalidad (Libéralité), la Dádiva o Generosidad (Présents), y el Tesoro (Trésor). En el dibujo de Coypel falta la Posesión pacífica que aparece en el texto cervantino ${ }^{18}$.

En primer plano, delante de esos grupos, se encuentran las figuras, de don Quijote, a la izquierda, con sus armas, observando la escena y, a la derecha, Sancho Panza con un generoso plato de comida, y sin ningún interés aparente por la representación. Ambos están recostados, don Quijote de espaldas y Sancho de frente, invitando a la participación del espectador. La disposición bajo cada uno de los grupos actúa como contraposición a lo representado con ellos: el idealista Quijote con el Interés y el materialista Sancho con el Amor.

En cierta manera, el episodio refleja la afición que Cervantes sentía por los emblemas o jeroglíficos que tanto atrajo a los intelectuales y humanistas en el Renacimiento, siendo buena muestra de ello su coetáneo Sebastián de Covarrubias $^{19}$ (1539-1613).

El segundo modelo a que hacemos referencia es el modelo iconográfico inglés ${ }^{20}$. En este sentido hay que decir que en la Inglaterra del siglo XVIII también se

18 «Un conjunto alegórico cuyo significado último cobra mayor sentido si tenemos en cuenta una de las principales obras francesas de emblemas: Emblemes [...] nouvellement mis de Latin en françois (Metz, 1595) de Jean Jacques Boissard pone de manifiesto los obstáculos con los que el hombre virtuoso pero pobre (Amor/Basilio) se encuentra en su camino, frente a las facilidades que por el contrario permiten la Riqueza -vestida con ricas telas y adornos-, la Liberalidad-portando una cornucopia de abundantes riquezas y un compás- y la Dádiva, abrazada a la Liberalidad como cualidad que la complementa. No obstante, el hombre sabio, valiente -ambas características regidas por Minerva/Atenea-, prudente simbolizado por la ninfa con la lámpara de aceite (en relación a la parábola de las vírgenes prudentes y las vírgenes necias)- y noble -ninfa entregando una corona- tiene asegurado que sus virtudes y hazañas serán cantadas eternamente por la Fama (Poesía, con la trompeta de la fama y un vestido en el que se representa el firmamento). Para la identificación de las alegorías también se ha seguido la obra de Cesare Ripa, Iconología (Roma, 1593)». GONZÁLES MORENO, Fernando y URBINA, Eduardo, "Don Quichotte conduit par la Folie...", pp. 13-14. Véase también, PINILLO, Carmen, "Emblemas en el Quijote», pp. 97-101.

19 Cfr. BOUZY, Christian, "El Tesoro de los emblemas y jeroglíficos: Sebastián de Covarrubias iconólogo", Académica. Boletín de la Real academia Conquense de Artes y Letras, 6, 2011, pp. 131-142. 20 LUCÍA MEGÍAS, José Manuel, Leer el Quijote en imágenes..., pp. 314-378. 
impone la visión de un Quijote de tipo cortesano, cuya máxima expresión artística son Francis Hayman (1708-1776) y, sobre todo, John Vanderbank (1694-1739).

Es en este momento cuando se produce el triunfo de un nuevo modelo editorial con la primera edición de lujo del Quijote en 1738, edición monumental en español en cuatro grandes volúmenes ilustrados con 67 estampas grabadas por Gerard van der Gucht (1696-1776) siguiendo los dibujos del pintor John Vanderbank, y el primer retrato de Miguel de Cervantes, de William Kent (ca. 16851748), con la Vida de Cervantes escrita por D. Gregorio Mayáns y Siscar (16991781), que supone el primer estudio sistemático sobre Cervantes y un análisis de su obra que se encontrará, a partir de este momento, en numerosas ediciones y traducciones del Quijote tanto dentro como fuera de Inglaterra. Esta impresión sale de las prensas londinenses de los hermanos J. \& R. Tonson, utilizando un excelente papel y los mejores tipos. Fue patrocinada por el barón John Carteret (1690-1763), que había sido embajador de España en Londres, dedicada a su mujer, la condesa de Montijo (Dominga Fernández de Córdoba y Guzmán).

Tuvo tal éxito esta versión que se reeditará varias veces a lo largo de la centuria, abriendo el camino de transformación del Quijote de un libro jocoso en un libro clásico y moral ${ }^{21}$. En 1742, los Hermanos Tonson editaron una traducción al inglés, con los dibujos de Vanderbank y los grabados de van der Gucht, y, en 1755, el impresor londinense Millar publica una nueva traducción inglesa con 25 láminas calcográficas de gran tamaño firmadas por Hayman.

John Vanderbank fue pintor de historia, retratista e ilustrador de libros como el que nos concierne. Sus dibujos son de una excelente calidad, buena prueba de lo cual son los que realizó para el Quijote, de una sobria elegancia, como lo manifiesta la estilización de los gestos de sus personajes, y con un aire mucho más clásico que los dibujos de Coypel. Lord Carteret deseaba una salida del Quijote que estuviera en consonancia con sus ideas estéticas (y políticas), más cercanas al neoclasicismo. Para llevar a cabo este propósito, Lord Carteret se valdrá de la ayuda de John Oldfield, quien no solo establecerá el programa iconográfico sino que escribirá unas "Advertencias", verdadero ideario estético que se editarán al inicio del libro 22 . Para la edición se escogieron a los artistas

21 LUCÍA MEGÍAS, José Manuel, "El Quijote ilustrado: Siglos XVII-XVIII...», s. p. Véase también del mismo autor, "Imágenes para un libro universal: Don Quijote de la Mancha (1605-1905)», en TORRES SANTO DOMINGO, Marta (coord.), Don Quijote en el Campus..., pp. 121-151, en especial la p. 133; y para mayor información sobre las vicisitudes de la edición inglesa y el modelo inglés véase del mismo autor, Leer el Quijote en imágenes..., pp. 315-319.

22 LUCÍA MEGÍAS, José Manuel, "La edición del Quijote de Tonson (Londres, 1738)», en Folio Complutense Noticias de la Biblioteca Histórica de la UCM, s. p., en <http://www.ucm.es/BUCM/blogs/ Foliocomplutense/6539.php> (consulta realizada el 14 de febrero de 2013). Véase también del mismo 
más importantes del momento. Además de John Vanderbank, se contó con William Hogarth (1697-1764) y William Kent (1685-1748), y los grabadores George Vertue (1684-1759), Gerard van der Gucht y Claude du Bosc (1682-ca. 1745). Pero el proyecto no consistía solo en cuidar la edición, sino que tenía que estar acompañada de otros elementos que la hicieran ser única, que permitieran incidir en la nueva propuesta de lectura de corte neoclásico que se quiere difundir: la de la sátira didáctica ${ }^{23}$.

Como ejemplo mostramos la estampa de Basilio finge su suicidio [2], donde Basilio, después de simular su suicidio, «moribundo», pide la mano de Quiteria. Al contrario de lo que había dibujado Coypel, donde el personaje principal era don Quijote, aquí los personajes principales son Basilio pidiendo la mano de Quiteria, situados en un primer plano, rodeados por don Quijote y Sancho (a la derecha), el cura, Camacho y otros personajes. Vanderbank proporcionó modelos para grabados Ilenos de agudeza y de intención, y realizó algunas pinturas que repetían sus composiciones ${ }^{24}$. El análisis de los rasgos psicológicos de los personajes de la obra resultaba de gran interés para los artistas y lo reflejaban en los gestos con los que los presentaban.

Puede afirmarse sin temor que la mayor parte de las ilustraciones del siglo XVIII manifiestan cierta teatralidad en su composición, tanto por los gestos y posturas de los personajes, que recuerdan los dramas de la época, como por los ambientes donde se desarrollan los acontecimientos, exteriores o interiores, recordando los escenarios teatrales ${ }^{25}$. Como bien apunta Nigel Glendinning, "queda claro que las ilustraciones no pueden captar la riqueza multisensorial, ni abarcar toda a realidad ambigua o engañosa del Quijote. Pero no dejan de estimular al lector con su propia perspectiva sobre los sucesos, sus intentos de plasmar en los diseños el carácter y temperamento de los personajes, o sus deseos de reproducir los vestidos más apropiados para la historia» ${ }^{26}$.

autor, Don Quijote, un mito en papel, Catálogo de Exposición, Madrid, Comunidad de Madrid, 2005, pp. 72-77, en <http://eprints.ucm.es/6534/1/unmitoenpapel_(Cat\%C3\%A1logo).pdf> (consulta realizada el 15 de febrero de 2013).

23 LUCÍA MEGÍAS, José Manuel, "La edición del Quijote...», s. p.

24 PÉREZ SÁNCHEZ, Alfonso E., "Viaje por las caras del Quijote», s. p., en El Cultural, 06/01/2005, en $<$ http://www.elcultural.es/version_papel/ESPECIAL/11096/Viaje_por_las_caras_del_Quijote_por_Alfonso_E_ Perez_Sanchez> (consulta realizada el 19 febrero de 2010).

25 LENAGHAN, Patrick, "Retráteme el que quisiere pero no me maltrate". Un recorrido por la Historia de la ilustración gráfica del Quijote», en LENAGHAN, Patrick, Imágenes del Quijote. Modelos de representación en las ediciones de los siglos XVII a XIX, Catálogo de Exposición, Madrid, The Hispanic Society of America, Museo Nacional del Prado, Real Academia de Bellas Artes de San Fernando, Calcografía Nacional, 2003, pp. 15-43, en especial las pp. 24-27.

26 GLENDINNING, Nigel, "Venturas y desventuras del libro ilustrado: el caso del Quijote», ibid., pp. 4553 , en especial la p. 49. 
2. John Vanderbank, Las bodas de Camacho: Basilio finge su suicidio, edición: J. \& R. Tonson, Londres, 1738, Vida y hechos del ingenioso hidalgo Don Quixote de la Mancha. Grabador: Gerard Van der Gucht. <http://www.qbi2005.com/ imagenes/media/0000701285.jpg>

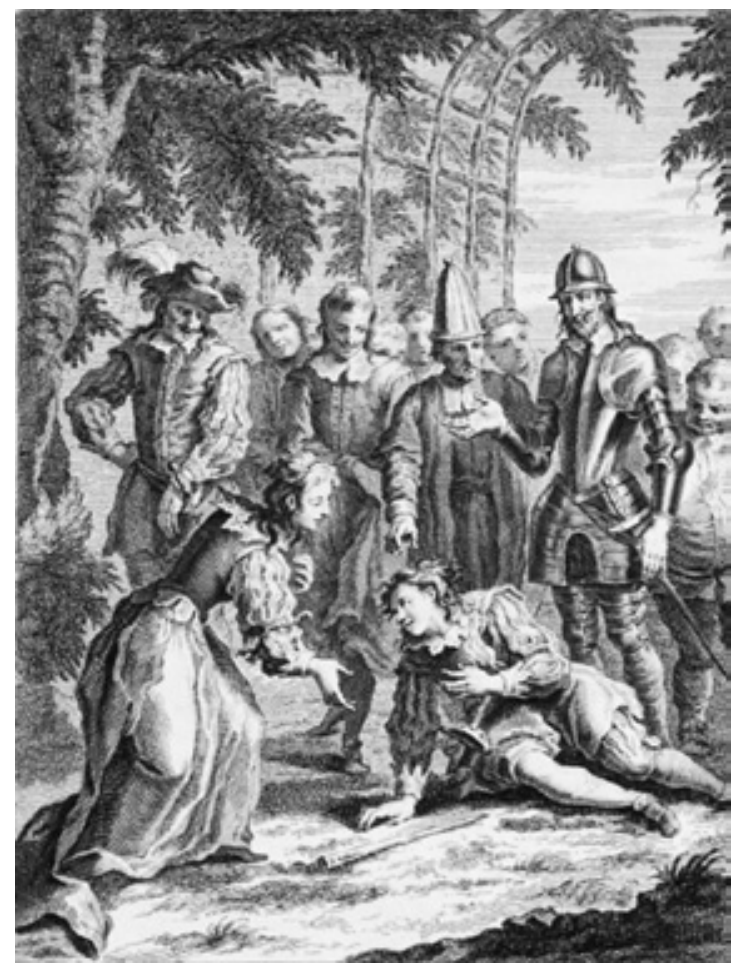

El tercer modelo que deseamos mostrar siguiendo a Lucía Megías es el modelo iconográfico españo ${ }^{27}$. El siglo XVIII en España se inaugura con la recién llegada dinastía borbónica y desde el primer rey Borbón, Felipe $V$, se encarga una serie de pinturas y tapices con temas del Quijote para decorar sus nuevos palacios. "Como puede verse, en las Cortes de Felipe $V$ y de su abuelo Luis XIV, la novela cervantina estuvo singularmente presente. En España, como si se quisiera subrayar la identificación de la nueva dinastía borbónica con la más expresiva de las novelas españolas del siglo precedente, y en Francia, al calor de una cierta "moda española" favorecida por las circunstancias históricas de acercamiento de ambas monarquías", como dice Pérez Sánchez ${ }^{28}$.

Entre las ediciones ilustradas de estos momentos, destaca de manera especial la de la Real Academia Española (fundada por Felipe $V$ hace 300 años, en 1713) en la que nos vamos a detener un momento.

27 LUCÍA MEGÍAS, José Manuel, Leer el quijote en imágenes..., pp. 379-454.

28 "Viaje por...", s. p., y "El Quijote en la pintura», p. 67. 
Hasta ahora todas las ilustraciones del Quijote tenían un aire extranjero. En España, a finales del siglo XVIII, en 1780, la docta institución sufragó una edición ilustrada para la que se llamó a artistas salidos, en su mayor parte, de la Real Academia de Bellas Artes de San Fernando (creada por Fernando VI en 1752). José del Castillo (1737-1793), Antonio Carnicero (1748-1814), Gregorio Ferro (1742-1812), Bernardo Barranco (1738-1791), incluso Goya (1746-1828), y otros pintores intentaron dar a las ilustraciones un carácter más español y «desplazar las intenciones risibles que impregnaban las ilustraciones hasta ahora vistas, sustituyéndolas por un tono más sereno, como entreviendo la profunda nobleza del personaje y de la historia» ${ }^{29}$. Asimismo se recurrió a los mejores grabadores del momento para ejecutar las incisiones.

La edición de $1780^{30}$, impresa por Joaquín Ibarra (1725-1785), uno de los mejores impresores que hayan existido, se considera como un monumento a la tipografía española, pues por vez primera se imprime la obra con todo cuidado y esmero, y en suelo español ${ }^{31}$. No tardó en convertirse en el referente

29 PÉREZ SÁNCHEZ, Alfonso E., "Viaje por...", s. p.

30 Miguel de Cervantes, El Ingenioso Hidalgo Don Quixote De la Mancha, nueva edición corregida por la Real Academia Española, 4 tomos en $4^{\circ}$ mayor, Madrid, Joaquín Ibarra, 1780. Esta edición contiene además de los 4 frontispicios, 31 láms., 15 en la parte primera y 16 en la segunda, de las cuales 19 fueron dibujadas por Antonio Carnicero, 7 por Joseph del Castillo, 2 por Bernardo Barranco, 1 por Joseph Brunete, 1 por Gerónimo Gil, 1 por Gregorio Ferro, siendo admirablemente grabadas por Francisco Muntaner, Joaquín Fabregat, Fernando Selma, Joaquín Ballester, Manuel Salvador Carmona, Pedro Pascual Moles, Juan Barcelón y Gerónimo A. Gil. De los 4 frontispicios, los que van en los tomos primeros son dibujos de Antonio Carnicero, grabados por Fernando Selma, y los que figuran en los dos últimos, fueron dibujados por Pedro Arnal y grabados por Juan de la Cruz. Para acrecentar más el valor artístico de esta edición, se estamparon hermosas viñetas en las cabeceras y remates de los capítulos, que fueron dibujadas por Antonio Carnicero, R. Ximeno y Cuesta, y las grabaron Juan Minguet, S. Brieva, M. Brandi, J. Palomino y Juan de la Cruz. El retrato de Cervantes, que sigue después del prólogo de la Academia, es copia del que regaló el Conde del Águila a dicha corporación, dibujado por J. del Castillo y grabado por Manuel Salvador Carmona. Véase una descripción más detenida en COTARELO MORI, Emilio, Catálogo de las obras publicadas por la Real Academia Española, Madrid, Tipografía de la «Revista de Archivos», 1928, ficha 346, pp. 68-69.

31 Son muchos los preparativos y los requisitos que impone la Academia para lograr una obra seria y responsable como nos describe José Manuel Lucía: «La empresa comenzó en 1773 y se tuvieron que resolver muchos asuntos por el camino: fijar el texto siguiendo unos criterios de apego a las primeras ediciones alejándose así de los deseos enmendadores de la edición de 1738 publicada en Londres, -fundir tres nuevos tipos de letra que se conocen como tipos Ibarra desde entonces-, fabricar papel especial, incorporar un "Análisis del Quixote", que lo firmará el teniente coronel Don Vicente de los Ríos, que muere antes de ver publicado su trabajo y, al mismo, tiempo cuidar el aspecto iconográfico, que, por los problemas surgidos en su realización, se verá drásticamente reducido. La Real Academia Española vigilará y mimará cada uno de estos detalles; en este sentido, será la corporación quien elija los episodios que deben ser ilustrados (documento conservado en el Archivo RAE, leg. 301, n. 5), y quien entregará a cada maestro dibujante los "Asuntos para las láminas que se han de poner en la obra de Don Quixote" Archivo RAE, leg. 301, n. 5), que está lleno de detalles. El programa inicial debía constar de 66 estampas (67 son las que aparecen en el interior de la edición de Londres de 1738), pero se reducirá a 32 estampas [...]", Don Quijote, un mito..., p. 82. Para una mayor información sobre la edición de la Academia y los artistas colaboradores se puede consultar BLAS, Javier y MATILLA, 
más importante de las ediciones del Quijote, lo que contribuyó, no poco, a la fijación de los tipos protagonistas, sobre todo porque fueron repetidas sus ilustraciones en varias ediciones posteriores. Gracias a ello, la representación de todos los personajes, no solo los de Quijote y Sancho, de los ambientes tanto urbanos como paisajísticos, de las estancias, de los vestidos, de los peinados, se españolizan, adquiriendo una visión más cercana a nosotros, más comprensible y, también, más acorde a la que concibió Cervantes ${ }^{32}$.

Como ejemplo de la nueva concepción presentamos la escena de Basilio se casa con Quiteria [3] dibujada por Antonio (1748-1814) e Isidro Carnicero (1736-1804) siguiendo el estilo neoclásico imperante en el momento. En primer plano, Quiteria, de perfil clásico, arrodillada y ricamente vestida, toma la mano de Basilio, que "moribundo" se encuentra en brazos de don Quijote, el sacerdote los casa antes de que Camacho, escamado, se percate de la superchería de Basilio. Al fondo, grandes cestas con comida, y Sancho comiendo a dos carrillos ajeno a la escena principal.

En el siglo XIX, la imaginación romántica encuentra en la novela motivos excelentes para su exaltación. La figura artística que destaca sobre las demás es la de Gustavo Doré (1832-1883), pintor y escultor francés de grandes cuadros y esculturas monumentales, aunque donde triunfó fue en el ámbito de la ilustración de libros, más de 200 obras de los escritores más importantes del mundo, entre ellas El Quijote de Cervantes, en la edición de 1863, publicada por Hachette con la traducción de Louis Viardot (1800-1883). Doré confió a Héliodore Pisan (1822-1890) la realización de la totalidad de los 377 grabados, lo que supuso una gran novedad ${ }^{33}$.

Doré nos dejó una visión muy personal del libro, más narrativa y fantástica, "enlazando un apasionado romanticismo con un simbolismo ensoñador» ${ }^{34}$. Los dibujos aparecen como viñetas a la entrada y al cierre de cada capítulo, y cada tema, a su vez, muestra representaciones a página entera. Un buen ejemplo de

José Manuel, "Imprenta e ideología. El Quijote de la Academia, 1773-1780», en LENAGHAN, Patrick, Imágenes del Quijote..., pp. 73-89.

32 En 1782, la misma Academia publicó una nueva edición, más sencilla y económica, con 23 nuevas ilustraciones que sustituían a las de 1780, debidas a los hermanos Antonio e Isidro Carnicero, reeditadas de nuevo en la edición de 1787. Para la descripción del contenido, véase COTARELO MORI, Emilio, Catálogo, fichas 347 y 348, pp. 69-70. En 1797 apareció una nueva edición por la Imprenta Real y, ese mismo año, otra del impresor madrileño Gabriel de Sancha, que incorporó 29 nuevas ilustraciones de José Camarón y Bonanat, Agustín Navarro, Luis Paret y Rafael Ximeno. Véase al respecto, LUCíA, José Manuel, Don Quijote, un mito..., p. 90; PÉREZ SÁNCHEZ, Alfonso E., "Viajes por...». s. p.; y RINCÓN GARCÍA, Wifredo, "Visiones de El Quijote en el arte español», p. 187, en <http://biblioteca2.uclm.es/ biblioteca/Ceclm/ARTREVISTAS/Cem/CEM_29_visiones_garcia.pdf> (consulta realizada el 13 de febrero de 2013).

33 HARTAU, Johannes, "Algunas representaciones iconográficas...", pp. 20-24.

34 PÉREZ SÁNCHEZ, Alfonso E., "Viaje por...", s. p. 


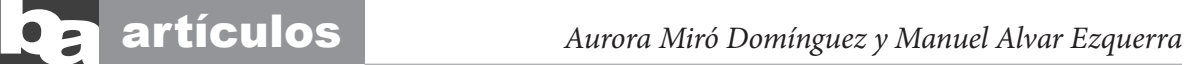

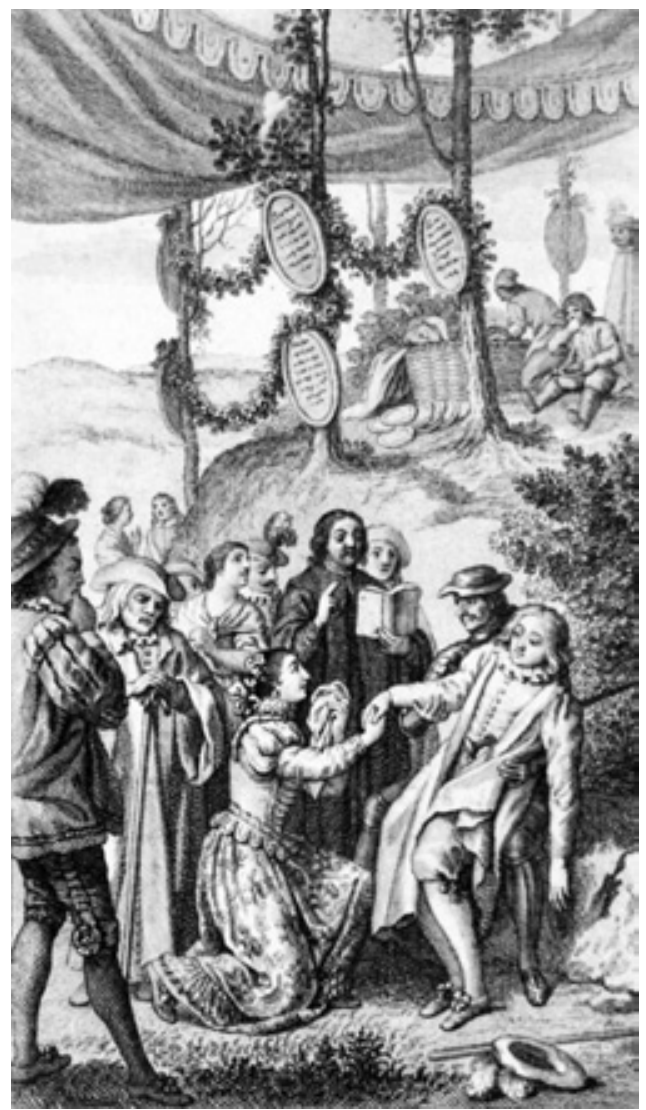

3. Basilio se casa con Quiteria. Isidro y Antonio Carnicero, dibujantes, y Antonio Selma, grabador: El ingenioso hidalgo don Quijote de la Mancha (Edición 1782, Madrid, Joaquín Ibarra, a costa de la Real Academia Española). <http://www.qbi2005.com/imagenes/ media/0000901423.jpg>

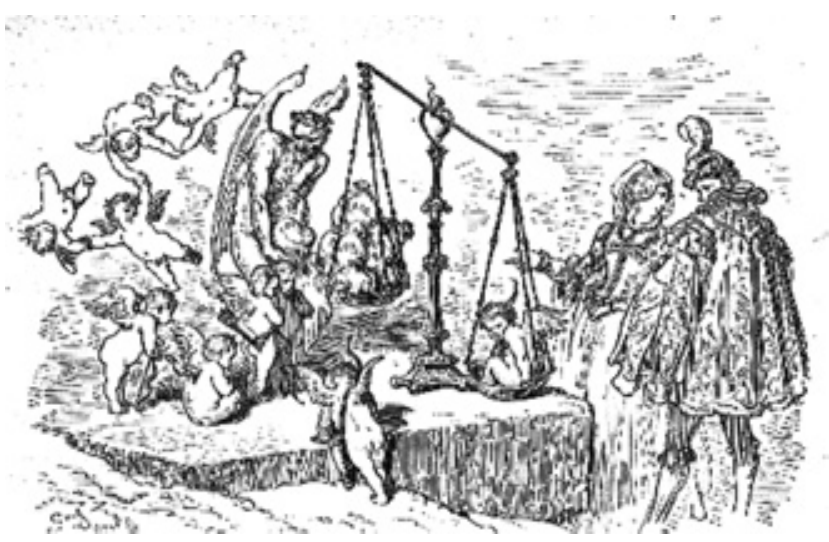

4. Gustavo Doré. Alegoría del Amor y del Interés o El dilema de Quiteria: dinero o amor, París, Librería de L. Hachette y Cia, 1863. Grabador: Pisan, Héliodore Joseph. $<$ http://www.h-net. org/ cervant/doreimag/ chisc131.gif> 


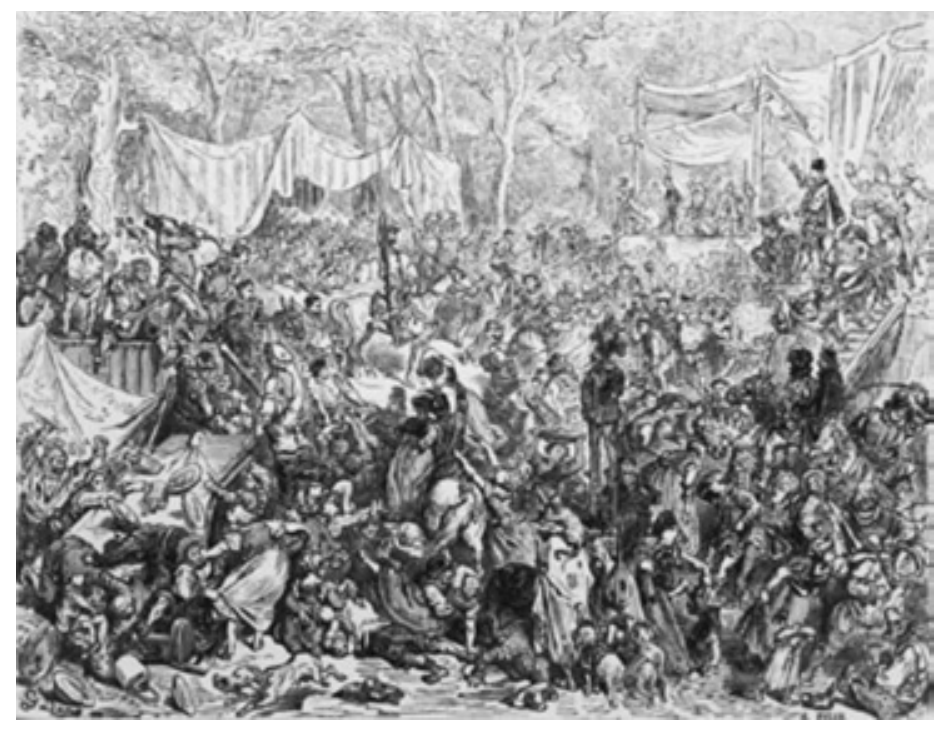

5. Gustavo Doré. Llegada a las bodas de Camacho, Edición: L'ingénieux hidalgo Don Quichotte de la Manche, Paris, Hachette, 1863. Grabador: Pisan, Héliodore Joseph. <http://www.qbi2005.com/imagenes/media/0000601091.jpg>

las viñetas es La alegoría del Amor y del Interés, también llamado El dilema de Quiteria: dinero o amor [4], completamente distinta de la interpretación de Coypel. Es una representación simbólica, muy original, de la confrontación entre Camacho y Basilio. Una joven pareja observa cómo un demonio ha colocado en un platillo de una balanza unas bolsas de dinero (que simbolizan a Camacho) y un pequeño Cupido en el otro (el amor verdadero, Basilio). Revoloteando alrededor aparecen otros cupidos juguetones y saltarines que proporcionan una gran animación al conjunto. El dibujo es excelente y muy imaginativo.

Ejemplo de láminas a toda página es la Llegada a las bodas de Camacho [5] que muestra la maestría de Doré para representar el bullicio y la alegría de la celebración de la boda con esa variada multitud de personajes, captada con gran observación y tanto detalle. El punto de vista es muy alto, con lo que consigue darnos una amplia perspectiva. Los numerosísimos personajes están contemplados en las más variadas actitudes y violentos escorzos (músicos en los escenarios, los cocineros, hombres peleando, niños llorando, jinetes, bailarinas, mendigos, etc.). En el centro, entre esa vorágine, nuestros protagonistas, don Quijote y Sancho, sobre Rocinante y el asno. 
Una de las características más sobresalientes de Doré es su desbordada imaginación, que se manifiesta claramente en el frontispicio de la obra, que se titula Son Imagination se remplit de tout ce qu'il avait $l u^{35}$, que coincide con la frase del primer capítulo del libro: «Llenósele la fantasía de todo aquello que leía en los libros".

Para realizar los bocetos de las ilustraciones del Quijote, Doré recorrió España captando con gran precisión los detalles la vida cotidiana. Con su capacidad observadora nos da en sus estampas una visión clara de las costumbres locales bastante realista, sin adornos, tanto para representar los personajes como los paisajes; la indumentaria, la arquitectura y, en general, todos los detalles, responden a esa visión realista. El Quijote de Doré es, tal vez, el más popular de todos y el que más éxito internacional ha tenido, siendo su acogida por el público muy amplia hasta nuestros días, de lo que habla la cotización que alcanzan en el mercado de anticuariado las ediciones con sus ilustraciones.

Como muestra de la repercusión de Doré, ofrecemos una de las muchas reproducciones que se realizaron de sus grabados, El cocinero agasaja a Sancho [6], en la versión en acuarela que realizó Salvador Tusell para la edición de $1905^{36}$. El cocinero está ofreciendo a Sancho una cazuela con tres gallinas y un par de gansos, según el texto cervantino, aunque más parecen conejo o liebre, mientras don Quijote observa la escena desde su rocín. Es muy interesante el gesto dubitativo de Sancho Panza, pues no sabe por dónde comenzar a comer aquello, con una sonrisa que denota su alegría (Doré representaba los caracteres con un fino sentido psicológico). En la parte inferior, tres niños están comiendo entre los perros uno de los cuales trata de quitarle su tajada a un niño, mientras que otro can lleva algo de comida en la boca, un añadido pintoresco y anecdótico en la imagen que, por lo demás, se corresponde exactamente con el texto cervantino ${ }^{37}$.

35 Puede verse en <http://mcv.revues.org/docannexe/image/1692/img-6-small480.jpg> (consulta realizada el 23 de febrero de 2013).

36 El ingenioso hidalgo Don Quijote de la Mancha, Barcelona, Viuda de Luis Tasso, s. f. [1905] (en el catálogo de la Biblioteca Nacional de España, Madrid, aparece con la fecha de 1900), que puede verse en <http://www.qbi2005.com>, consulta realizada el 18 de febrero de 2013).

37 "Todo lo miraba Sancho Panza, y todo lo contemplaba, y de todo se aficionaba: primero le cautivaron y rindieron el deseo las ollas, de quién él tomara de bonísima gana un mediano puchero; luego le aficionaron la voluntad los zaques; y, últimamente, las frutas de sartén, si es que se podían llamar sartenes las tan orondas calderas; y así, sin poderlo sufrir ni ser en su mano hacer otra cosa, se llegó a uno de los solícitos cocineros, y, con corteses y hambrientas razones, le rogó le dejase mojar un mendrugo de pan en una de aquellas ollas. A lo que el cocinero respondió: Hermano, este día no es de aquellos sobre quien tiene juridición la hambre, merced al rico Camacho. Apeaos y mirad si hay por ahí un cucharón, y espumad una gallina o dos, y buen provecho os hagan. No veo ninguno respondió Sancho. Esperad dijo el cocinero. ¡Pecador de mí, y qué melindroso y para poco debéis de ser! Y, diciendo esto, asió de un caldero, $y$, encajándole en una de las medias tinajas, sacó en él tres gallinas y dos gansos [...]», Quijote II-XX. 


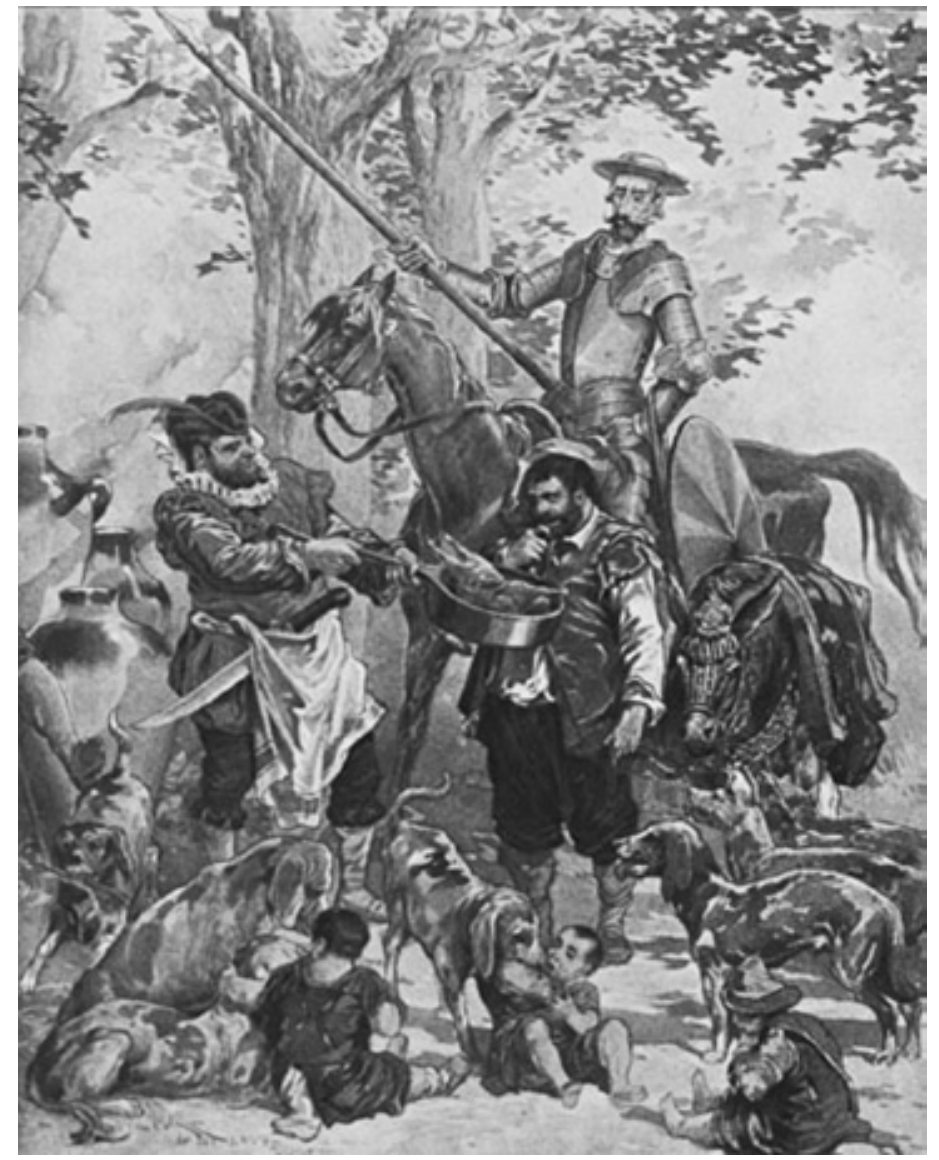

6. Gustavo Doré. El cocinero agasaja a Sancho, reproducción de la ilustración de Doré (Paris: Hachette, 1863), acuarela de Salvador Tusell. El ingenioso hidalgo Don Quijote de la Mancha, Barcelona, 1905, Viuda de Luis Tasso. Leyenda: «Esperad, dijo el cocinero, ¡pecador de mí, y qué melindroso y para poco debéis de ser!» (Tomo I, cap. XX). <http://www.qbi2005.com/imagenes/media/0007804499.jpg>

En España, como es lógico, el contenido de la obra se constituyó en fuente primordial para la representación, pues se convirtió en símbolo nacional, y se recurría a ella en todas las ocasiones en que había que expresar el orgullo nacionalista. Desde el siglo XVIII, el libro de Cervantes produjo una gran fascinación a los artistas españoles, debido al gran auge del costumbrismo popular que se había puesto de moda por la sociedad ilustrada para ornamentar sus residencias, ya fuera con cuadros ya con tapices. 
Una versión romántica del tema es el cuadro del Casamiento de Basilio y Quiteria [7], obra de Manuel García, conocido por su sobrenombre Hispaleto (1836-1898), pintor sevillano que realizó algunas de las mejores obras de su producción recreando escenas del texto cervantino ${ }^{38}$. Fue un artista afamado que se destacó por sus retratos y sus cuadros de carácter histórico, literario y costumbrista. Es la segunda obra de tema cervantino con la que Hispaleto se presenta a una Exposición Nacional de Bellas Artes, la de 1881, por la que obtuvo una segunda medalla. Fue su obra más ambiciosa por el tamaño y concepción escenográfica y decorativa.

Hispaleto nos deja una visión realista muy personal, con un dibujo firme y certero, así como una variedad de tipos humanos inspirados en personajes elegantes, cotidianos, de su entorno, con indumentarias de una gran riqueza y colorido, sin descuidar ningún detalle en los adornos y riqueza de las telas. El ambiente está muy conseguido, situando la escena principal en primer plano, y alejando el resto por medio de una perspectiva en fuga hacia el fondo claro del horizonte. Otra de las características de su obra «es su destreza en la acumulación de figuras, con un gran efecto narrativo y anecdótico, imprimiendo una sensación verdadera de agitado tumulto, al desplegar una gran variedad en las actitudes y expresión de los afectos de cada uno de ellos, con un lenguaje gestual marcadamente teatral, de indudable efecto" ${ }^{39}$, que se ve en el cuadro que nos ocupa. A ambos lados y al fondo se despliega una serie de grupos de personajes, cocineros, músicos, lugareños que animan el festejo, con gran detallismo realista en algunos instrumentos musicales, tinajas y rostros de los personajes de los primeros planos, que son verdaderos retratos tomados del natural. La representación pictórica se ajusta al texto de Cervantes ${ }^{40}$.

Del siglo $\mathrm{XX}$, a pesar de que son muchísimos los artistas, alguno de ellos grandes figuras, que en algún momento representan el Quijote, son pocos los que ilustran las bodas de Camacho. Por falta de espacio, hemos seleccionado dos obras muy diferentes.

La colosal composición de las Bodas de Camacho de José María Sert (18741945) formaba el panel central de los quince murales de temas populares que

38 DíEZ, José Luis, "Cervantes y el Quijote en la pintura andaluza del siglo XIX», en DíEZ, José Luis (dir.), Una visión ensoñada del Quijote. La serie cervantina de Muñoz Degrain en la Biblioteca Nacional, Catálogo de Exposición, Fundación Focus-Abengoa, Hospital de los Venerables, Sevilla, 2003, pp. 25-45, en especial las pp. 32-34.

39 Ibid., p. 33.

40 Véase también la descripción que hace de este cuadro Enrique Valdivieso González en "Temas cervantinos en la pintura sevillana decimonónica", en Boletín de la Real Academia sevillana de Buenas Letras, 24, 1996, pp. 141-159, en especial las pp. 149-150. 


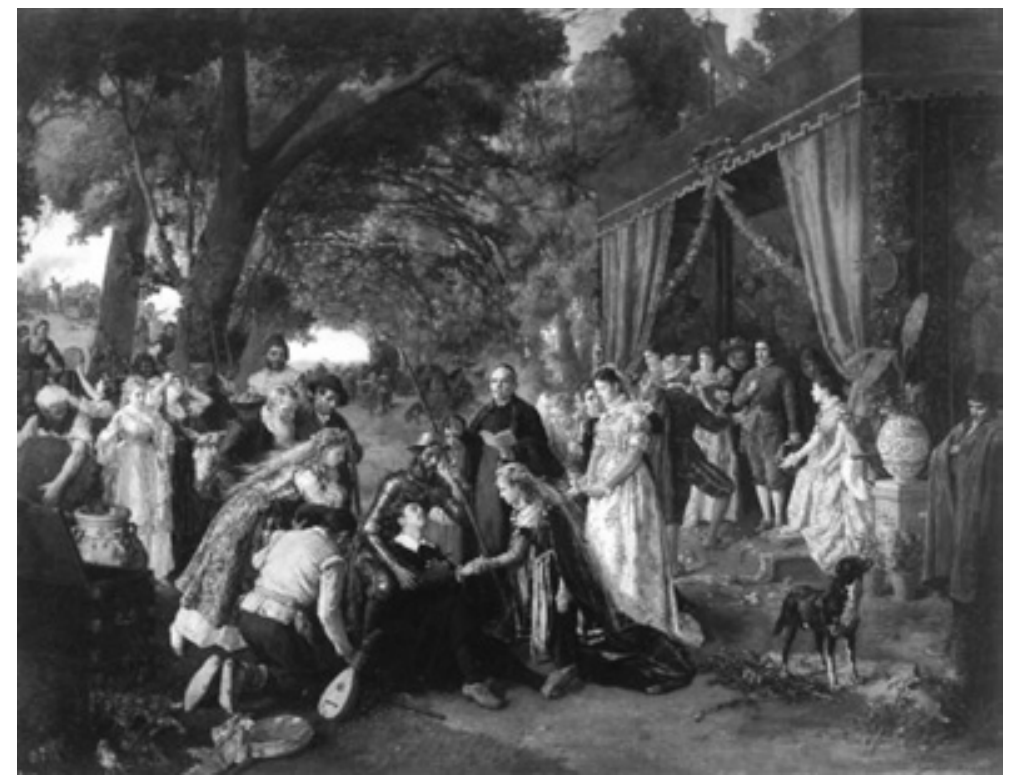

concibió para la decoración del comedor del Hotel Waldorf Astoria de Nueva York, realizada entre 1929 y 1930, pocos años después de que Joaquín Sorolla (1863-1923) pintase los murales de la Hispanic Society of America (entre 1913 y 1919), con escenas costumbristas de España y Portugal. Fue el primer encargo internacional del artista catalán. En el hotel las obras de Sert alcanzaron tanta popularidad, que hizo que al comedor se le llamase Salón Sert. Los lienzos estuvieron allí hasta 1972. En la actualidad pertenecen a la Colección Santander Central Hispano cedidos a la ciudad de Vic ${ }^{41}$.

Sert fue un pintor que destacó sobre todo como muralista. Ideó un estilo propio, inspirado en la pintura manierista y barroca como podemos observar en Las bodas de Camacho [8]. La perspectiva utilizada es casi de sotto in su, con figuras populares que se disponen en una arquitectura escalonada, con claros

41 Puede verse en <http://contenidos.universia.es/especiales/sala-arte/mejores-obras/sert/index.htm>y $<$ http://www.factum-arte.com/eng/conservacion/sert/default.asp > (consultas realizadas el 25 de febrero de 2013). 


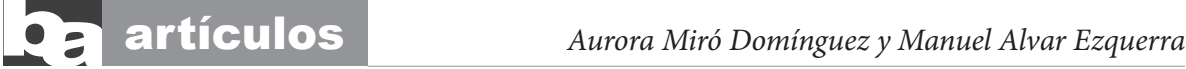

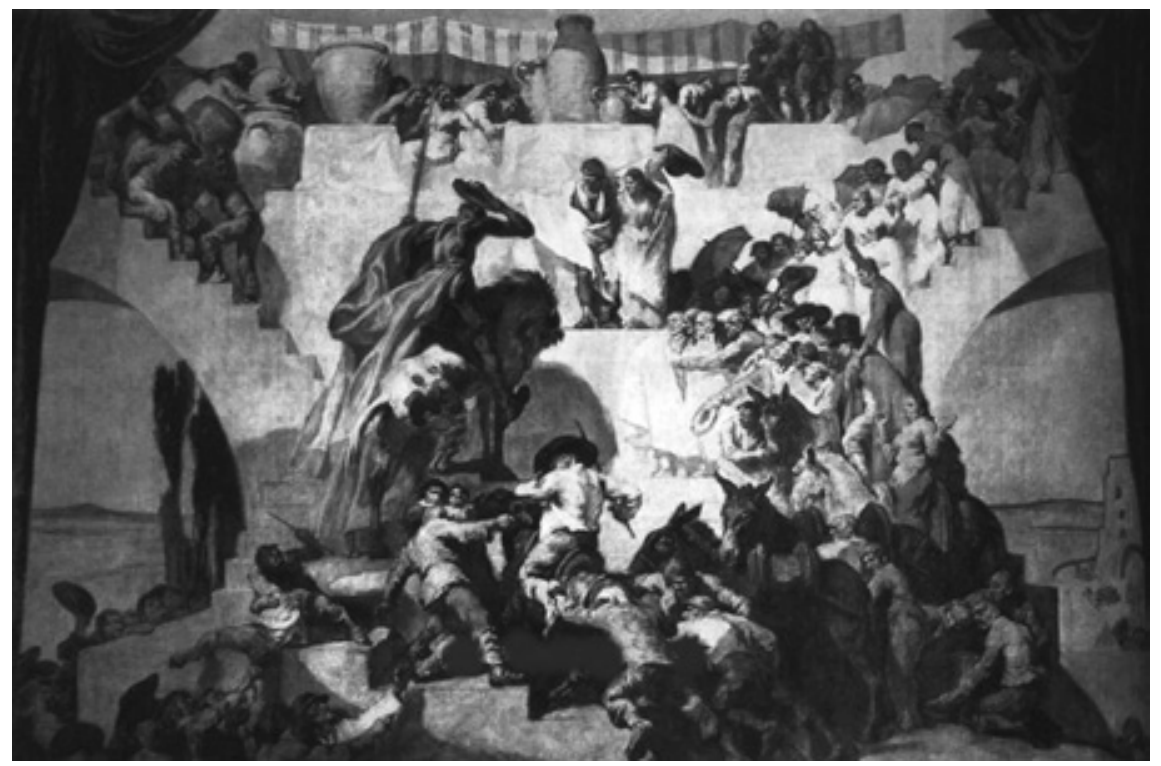

8. Josep María Sert: Las Bodas de Camacho, decoración del comedor del Hotel Waldorf Astoria de Nueva York, 1929-1930, Grisalla en negro y oro sobre lienzo, 420 x $640 \mathrm{~cm}$ ). <http://www.epdlp.com/fotos/jmsert3.jpg>

ecos miguelangelescos por su corpulencia y sus violentos escorzos. En cuanto a la técnica empleada no era propiamente pintura mural, sino que utilizaba lienzos que luego pegaba a las paredes. La composición es casi monocroma, pues utilizaba prácticamente dos colores: negro y oro, con lo que conseguía una especie de grisalla, con una gama cromática limitada: oros, ocres, tierras tostadas, con toques de carmín, y como fondo una rica preparación en metal, plata, panes de oro, para conseguir un efecto de daguerrotipo. Es una grandiosa composición decorativa, donde lo más interesante es "la audacia en los escorzos y la dimensión espectacular de los escenarios» ${ }^{42}$.

Por último, deseamos acabar con el enfoque que nos dejó Enrique Herreros (1903-1977) de Las Bodas de Camacho. Ha sido el único artista español que ilustró tres ediciones distintas del Quijote: el Quijote humorista o codornicesco (1948-1960), el Quijote en blanco y negro o expresionista (1966); y el Quijote 
9. Enrique Herreros: Las principales aventuras de Don Quijote, Madrid,

Editora Nacional, 1964. <http://hera.uclm.es:8080/ Iconography/DQIIMAGES/ images/254/1964-Madrid-

Nacional-01-043.jpg>

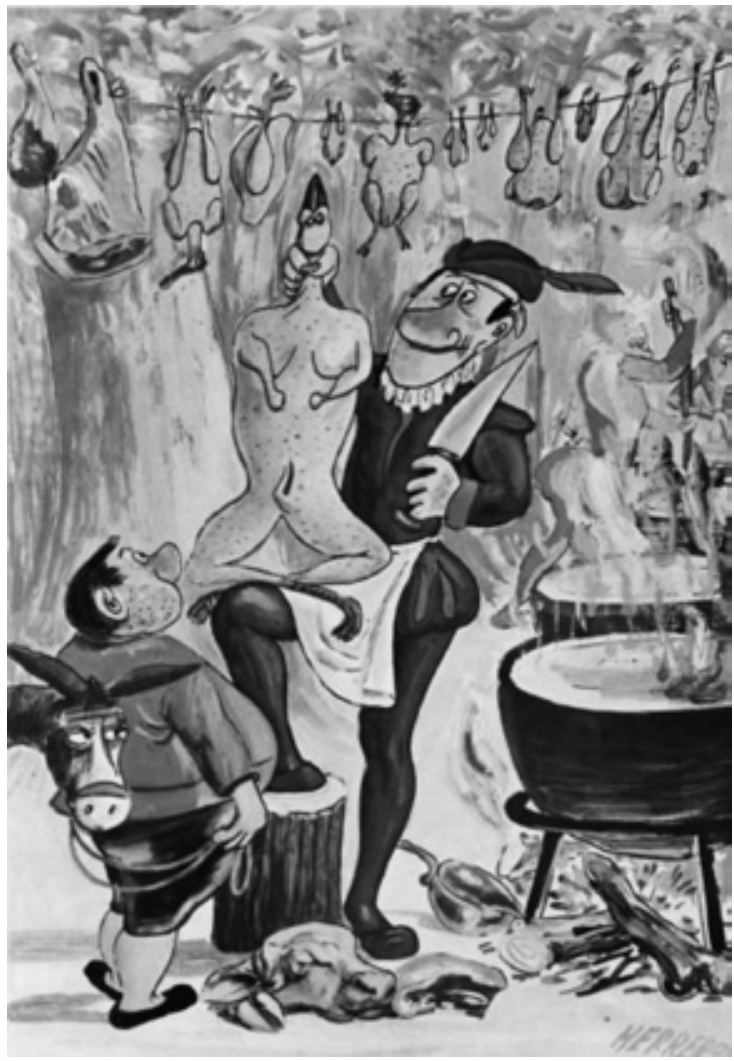

cubista (1965-1967) ${ }^{43}$, "que reflejan la versatilidad de este artista polifacético» ${ }^{44}$. La lámina que hemos escogido de Las bodas de Camacho [9] ilustra el momento en que Sancho Panza llega al lugar donde los cocineros estaban preparando la comida de la boda: "[...] y seis ollas que alrededor de la hoguera estaban no se

43 Referencias bibliográficas: del Quijote humorista o codornicesco, CERVANTES SAAVEDRA, Miguel de, El Ingenioso Hidalgo Don Quijote de la Mancha, con ilustraciones de Enrique Herreros, Madrid Editora Nacional, 1964 ( $2^{a}$ ed. 1966); del Quijote en blanco y negro o expresionista, CERVANTES SAAVEDRA, Miguel de, El Ingenioso Hidalgo Don Quijote de la Mancha, con ilustraciones se Enrique Herreros, prólogo de Francisco Umbral, Madrid, Edaf, 1999; y del Quijote cubista, CERVANTES SAAVEDRA, Miguel de, El Ingenioso Hidalgo Don Quijote de la Mancha, con ilustraciones de Enrique Herreros, prólogo de F. R. Lafuente, Madrid, Ayuntamiento de Madrid, Edaf, 2002. Véase también, LUCÍA MEGÍAS, José Manuel y otros (eds.), Summa Cervantina de Enrique Herreros, Madrid, Edaf, 2011, donde por primera vez se publican juntas todas las ilustraciones que hizo sobre el Quijote Enrique Herreros (1903-1977).

44 ALAMINOS LÓPEZ, Eduardo, "La arborescente iconografía de El Quijote», en Los Quijotes de Enrique Herreros (1903-1977), Catálogo de Exposición, octubre-noviembre, 2005, Museo Municipal de Arte Contemporáneo, Ayuntamiento de Madrid, 2005, pp. 59-69, en especial la p. 67. 
habían hecho en la común turquesa de las demás ollas, porque eran seis medias tinajas, que cada una cabía un rastro de carne: así embebían y encerraban en sí carneros enteros, sin echarse de ver, como si fueran palominos; las liebres ya sin pellejo y las gallinas sin pluma que estaban colgadas por los árboles para sepultarlas en las ollas no tenían número; los pájaros y caza de diversos géneros eran infinitos, colgados de los árboles para que el aire los enfriase».

Nuestra imagen pertenece al primer Quijote, el codornicesco, no en vano fue cofundador de la popular revista La Codorniz y uno de sus mejores artífices. Lo diseñó con 72 ilustraciones realizadas sobre cartulina a pluma, pincel, lápiz, guache, tinta china y un toque al óleo en color, con esa mirada humorística e irónica ante la realidad.

Con estas pocas páginas hemos querido dejar testimonio de nuestro reconocimiento profesional y personal a nuestra buena amiga y excelente colega Rosario Camacho. Su generoso desprendimiento hace que lo que ofrece por liberalidad se confunda hasta el hastío con la opulencia de aquel otro Camacho, tan presente en el arte. 